
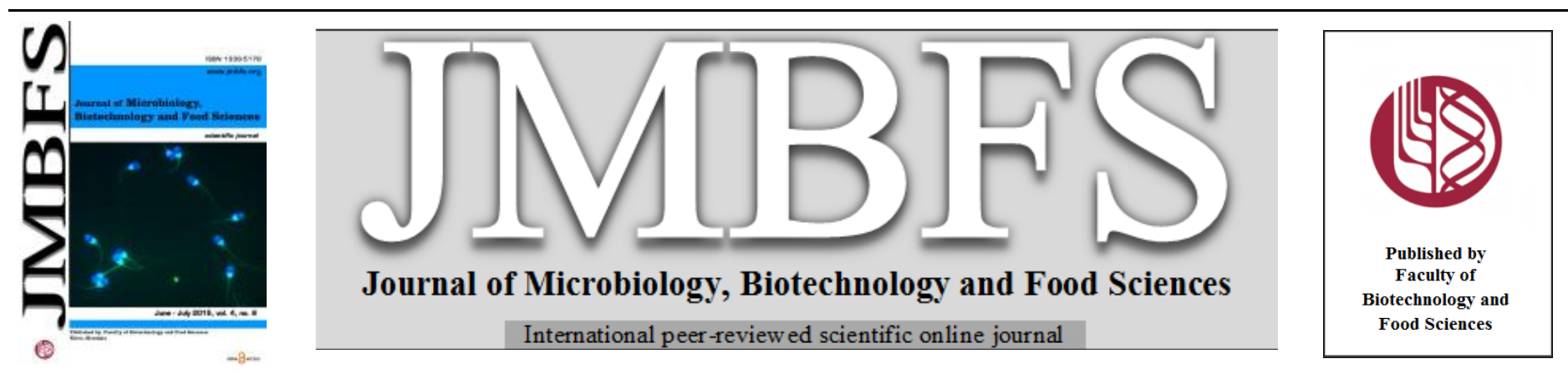

\title{
PRODUCTION OF LIPASES IN SOLID-STATE FERMENTATION BY Aspergillus niger F7-02 WITH AGRICULTURAL RESIDUES
}

\section{Olayinka Quadri Adio ${ }^{1}$; Sarafdeen Olateju Kareem ${ }^{1}$; Michael Bamitale Osho ${ }^{2}$ and Adebukola Mobolaji Omemu ${ }^{3}$}

$\operatorname{Address(es):~Dr.M.~B.~Osho,~}$

${ }^{1}$ Federal University of Agriculture, College of Natural Sciences, Department of Microbiology, Abeokuta, P.M.B. 2240, Abeokuta, Ogun State, Nigeria.

${ }^{2}$ McPherson University, College of Natural and Applied Sciences, Department of Biological Sciences,Seriki-Sotayo, P.M.B 2094,Abeokuta, Ogun State, Nigeria. +2348032698955; +2347083887538

${ }^{3}$ Federal University of Agriculture, College of Food and Human Ecology, Department of Food Service and Tourism, Abeokuta, P.M.B. 2240, Abeokuta, Ogun State, Nigeria.

*Corresponding author: osho_michael@ rocketmail.com

doi: 10.15414/jmbfs.2015.4.6.509-512

\section{ARTICLE INFO}

Received 1. 10. 2014

Revised 6. 3. 2015

Accepted 6. 4. 2015

Published 1. 6. 2015

$\underline{\text { Regular article }}$

open $\odot$ access

\begin{abstract}
In this study mould strains screened and molecularly identified as Aspergillus niger F7-02 was used to produced extracellular lipase in Solid State Fermentation (SSF) process. Different agricultural residues were combined in different ratios as carbon, nitrogen and elemental sources in the solid culture medium. The optimization of the culture medium was carried out for such parameters as incubation time $(24 \mathrm{~h}-96 \mathrm{~h})$, inoculum concentration $(0.5-3.0 \%, \mathrm{w} / \mathrm{v})$, initial moisture content $(40-70 \%$, w/v), and initial $\mathrm{pH}(6-8)$ for maximum yield. The maximum lipase activity of $76.7 \mathrm{U} / \mathrm{ml}$ was obtained with a medium containing rice bran (RB), palm kernel cake (PKC), groundnut cake (GNC) and starch (S) at the ratio of 5:5:3:1 (\%w/w) with optimum conditions of $60 \%$ moisture, $1 \%$ inoculum and a $\mathrm{pH}$ of 7.0 with an incubation temperature of $30{ }^{\circ} \mathrm{C}$ and incubation time of $72 \mathrm{~h}$.
\end{abstract}

Keywords: Agricultural waste, Aspergillus niger F7-02, lipase, optimization, solid state fermentation

\section{INTRODUCTION}

Lipases are hydrolytic enzymes that act in aqueous-organic interfaces, catalyzing the cleavage of ester bonds in triglycerides and producing glycerol and free fatty acids (Freire and Castilho, 2000). There has been a growing interest for lipases of microbial origin since the eighties. Lipases find an increasing range of applications due to the different catalytic reactions and their regio and enantio selectivity in detergents, foods, pharmaceuticals, fine chemicals, leathers and pulp and paper industries (Freire and Castilho, 2000). However, the development of low-cost processes for the production of lipases create a greater industrial application for these enzymes. In this context, solid-state fermentation (SSF) is an interesting low-cost alternative for the production of biomolecules. Solid State Fermentation has great potentials due to its simplicity of operation, low capital cost and high volume productivity (Akpan et al., 1999) and has gained renewed interest because of its potential to produce higher yields of fungal metabolites than submerged fermentation (Akpan and Adelaja 2004). In SSF, agroindustrial residues can be employed as culture medium. These low-cost and abundant raw materials contribute to reduce production costs (Freire and Castilho, 2000). Many agricultural products from cereals or legumes are cheap and readily available in the developing countries as sources of carbohydrates and proteins, so they could provide the required nutrients in the fermentation medium (Akpan et al. 1999). The use of agricultural products such as wheat bran solid medium for enzyme production has been well established, but it is scarce in the tropics. However, alternatives such as rice bran solid medium require supplements such as yeast extract and peptone; but these are expensive materials in the tropics (Akpan et al. 1999). The objective of our study was to investigate the synergistic effect of various agricultural residues (rice bran, palm kernel cake, soy bean, groundnut cake and starch) combined in different ratios (as sources of carbon, nitrogen and elemental supplements) as solid media to support the growth of Aspergillus niger F7-02 for lipase production.

\section{MATERIALS AND METHODS}

\section{Source of microorganisms}

Mould strains were isolated from soil samples obtained from a compost farm at the Federal University of Agriculture, Abeokuta, Nigeria. Screening was done by plating decimal dilutions $(0.1 \mathrm{ml})$ of suitably diluted soil samples on Sabourand dextrose agar (SDA) incubated at $30^{\circ} \mathrm{C}$ for $48 \mathrm{~h}$. Pure isolates were obtained by sub-culturing and were maintained on SDA agar slants at $4{ }^{\circ} \mathrm{C}$ and sub-cultured bimonthly.

\section{Chemicals}

Tween 80 and Bromocresol green dye (3',3',5',5', Tetrabromo-mcresolfonephthalein) were purchased from SIGMA CHEMICALS LTD, USA., PCR ladder, Ethidium bromide, PCR Master mix (NORGEN), Primers ITS 4 Reverse (MACROGEN INC. USA) and ITS 86- Forward (EUROFINS MWG OPERON, HUNTSVILLE) TEXAS, UNITED STATE. All chemicals were of analytical grade (ANALAR).

\section{Substrates}

Rice bran (RB), Palm kernel cake (PKC), Soy bean (SB), Groundnut cake (GNC) and $\operatorname{Starch}(\mathrm{S})$ were purchased from KUTO market, ABEOKUTA SOUTH LOCAL GOVERNMENT AREA, OGUN STATE, NIGERIA.

\section{Screening of lipase positive moulds}

This was carried out according to the method described by Akpan (2004). The plate medium consisted of Sabouraud dextrose agar (SDA) and $0.1 \%$ bromocresol green. The medium was sterilized at $121{ }^{\circ} \mathrm{C}$ for $15 \mathrm{~min}$. While still warm, sterile Tween 80 (1\%) was added and mixed properly. Sterile plates were poured and inoculated with pure isolates of A. niger F7-02 and were incubated at $30{ }^{\circ} \mathrm{C}$ for $72 \mathrm{~h}$. Lipase production was detected by a colour change (green to yellow) around the colonies. The diameter of the zones of hydrolysis were measured with a Venier caliper. Mould strains with the widest zone of hydrolysis were picked and stored at $4{ }^{\circ} \mathrm{C}$ for further studies.

\section{Identification of lipase positive moulds}

The lipase positive moulds were identified according to the methods of Barnet and Hunter (1972). Wet preparation of isolates were prepared with Lactophenol blue and observed under X40 power objective lens of a light microscope. 
Nucleotide sequences were determined by analysis of fluorescently labeled DNA products generated by $2 \mathrm{X}$ PCR Master mix on an AB373a Strech (short gun) DNA sequencer. Reverse primer ITS4 (5'-TCCTCCGCTTATTGATATGC-3') and forward primer ITS86F (5'-GTGAATCATCGAATCTTTGAA-3') were used in all sequencing reactions. The obtained sequences of genomic DNA were aligned by submitting them to the non-reductant nucleotide database at Genbank using the BLAST program in order to determine the identity of the isolates (http://www.ncbi.nlm.nch.gov).

\section{Preparation of inocula}

Fungal spores $(1 \mathrm{~g})$ were suspended in $10 \mathrm{ml}$ of sterile water and $1 \mathrm{ml}(10 \% \mathrm{w} / \mathrm{v})$ of suspension was used as inocula (Kareem and Akpan, 2003).

\section{Media development}

Six different solid fermentation media were formulated using various agricultural residues to support the growth of the moulds for lipase production: rice bran (RB), palm kernel cake (PKC), soy bean (SB), groundnut cake (GNC) and starch (S) combined in following ratios:

Medium I: RB, PKC, GNC and S (5:5:3:1\%w/w);

Medium II: RB, GNC, S (10:3:1\%w/w);

Medium III: PKC, GNC, S (10:3:1\%w/w);

Medium IV: RB, SB, S (10:3:1\%w/w);

Medium V: RB, SB, S, V1 (10:3:1\%w/w) + Vegetable oil (1 ml);

Medium VI: RB, SB, S, V2 (10:3:1\%w/w) + Vegetable oil $(2 \mathrm{ml})$;

Each medium was sterilized at $121{ }^{\circ} \mathrm{C}$ for $15 \mathrm{~min}$ and inoculated with $1 \mathrm{ml}$ of spore suspension of A.niger F7-02 and incubated at $30{ }^{\circ} \mathrm{C}$ for $72 \mathrm{~h}$. Various process parameters such as incubation time $(24-96 \mathrm{~h})$; inoculum concentration $(0.5-3.0 \% \mathrm{w} / \mathrm{v})$; solid substrate moisture content $(40-70 \%)$ and initial $\mathrm{pH}(6.0$ 8.0 ) were optimized by conventional method for maximal lipase production and their effects monitored.

\section{Crude enzyme recovery from mouldy rice bran}

This was carried out using the method of Kareem and Akpan (2003). Mouldy rice bran was dissolved in $50 \mathrm{mM}$ sodium phosphate buffer $\mathrm{pH} 8.0$ and the mixture was incubated at $4{ }^{\circ} \mathrm{C}$ for $3 \mathrm{~h}$ with intermittent shaking. The filtered extract was used as crude enzyme source.

\section{Titrimetric assay of lipase activities}

This was carried out by combined methods of Praphan and Kirk (2001) and Janaina et al. (2006). Lipase activities were assayed with olive oil emulsion substrate which was prepared by mixing $25 \mathrm{ml}$ of olive oil and $75 \mathrm{ml}$ of $7 \%$ Arabic gum solution in a rotary shaker at $150 \mathrm{rpm}$ for $5 \mathrm{~min}$. The reaction mixture contained $50 \mathrm{ml}$ of olive oil emulsion substrate and $10 \mathrm{ml}$ of crude enzyme which was incubated at $50{ }^{\circ} \mathrm{C}$ for $30 \mathrm{~min}$ under orbital shaker at $160 \mathrm{rpm}$. At five suitable reaction intervals $(5,10,15,20$, and $25 \mathrm{~min}), 5 \mathrm{ml}$ reaction mixture was removed and each subsample was transferred to a separate flask containing $10 \mathrm{ml}$ of $95 \%(\mathrm{v} / \mathrm{v})$ ethanol and three drops of $1 \%(\mathrm{w} / \mathrm{v})$ thymolphtalein indicator and was swirled to stop the reaction. The amount of released free fatty acids was titrated with $0.05 \mathrm{~N} \mathrm{NaOH}$ solutions and calculated according to the following equation.

$$
\begin{aligned}
& \mu m o l \text { fatty acid }(\mathrm{ml} \text { subsample }) \\
& =\frac{[(\mathrm{ml} \mathrm{NaOH} \text { for sample }-\mathrm{ml} \mathrm{NaOH} \text { for blank }) * N * 1000]}{5 \mathrm{ml}}
\end{aligned}
$$

Where $N$ is the normality of the $\mathrm{NaOH}$ titrant used ( 0.05 in this case)

One unit (U) of lipase activity is the amount of enzyme which liberates from emulsion substrate $1 \mu \mathrm{mol}$ of fatty acid per $\mathrm{ml}$ per minute under specific assay conditions.

\section{RESULTS}

\section{Isolation and screening of lipase positive moulds}

Of the fifty moulds isolated from the soil samples only five were positive for lipase production and only one was selected because of its widest zone of hydrolysis and high lipase activity as shown in Table 1. Appearance of zone of hydrolysis around A. niger F7-02 (Plate 1a) showed that the isolate was lipase positive while (Plate 1b) showed a non-lipolytic mould. Hydrolysis of olive oil by lipase producing moulds led to the release of fatty acid and glycerol and colour change in the medium from green to yellow due to the chromogenic bromocresol green indicator and change in the $\mathrm{pH}$ of the medium
Table 1 Screening of microorganisms for lipase production

Microorganisms

Clearance zones (mm) Lipase activity $(\mathrm{U} / \mathrm{ml})$

Aspergillus niger F7-02

7.0

Rhizopus sp

5.1

60.9

Penicillum sp.

4.0

41.7

Aspergillus oryzae

0.5

* Mean of triplicate determinations
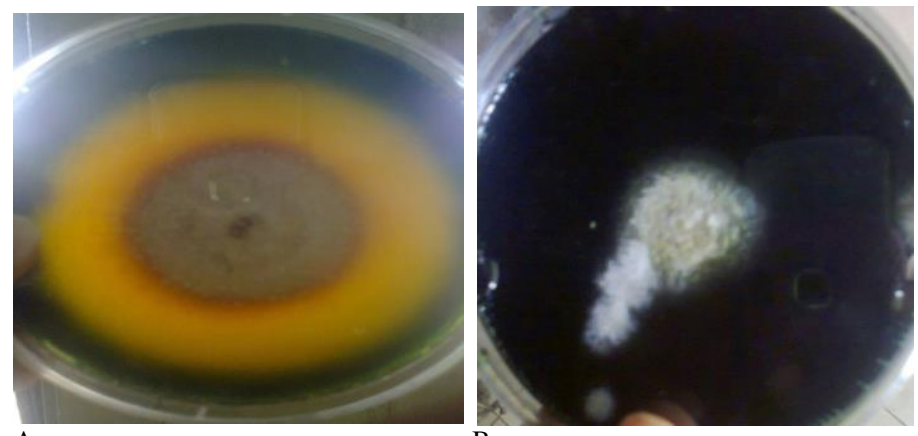

A

Plate 1 Lipase positive of Aspergillus niger F7-02 with clear zone of hydrolysis (A) and lipase negative (B) isolates on Bromocresol green agar

\section{Molecular identification}

The internal transcribed spacer (ITS) regions of ITS 86 and ITS 4, which are located between the highly conserved small (18S) ribosomal subunit genes in the rRNA of the lipase producing strain have sufficient sequence variability and were used for the identification of the isolate as Aspergillus niger F7-02. The molecular identification confirmed the isolate align with A. niger F7-02 of assertion number JN561274 with 98\% identity matching.

\section{Optimization studies on Solid State Fermentation Process for lipases production}

All the six media supported the growth of A. niger F7-02 with highest lipase activity of $76.7 \mathrm{U} / \mathrm{ml}$ after $72 \mathrm{~h}$ of incubation in medium 1 containing RB, PKC, GNC, S (5:5:3:1\%w/w) (Figure 1). Medium II which contained RB, GNC, S $(10: 3: 1 \% \mathrm{w} / \mathrm{w})$ had a lower activity of $38.5 \mathrm{U} / \mathrm{ml}$ when compared to medium III which consisted of PKC, GNC, S (10:3:1 \%w/w) with activity of $57.4 \mathrm{U} / \mathrm{ml}$, which is the closest to activity recorded in medium I. Like the conventional rice bran solid substrate, medium IV [(RB, SB, S) 10:3:1\%w/w], had an activity of $49.5 \mathrm{U} / \mathrm{ml}$, and when vegetable oil was added (medium V) [(RB, SB, S, V1) $10: 3: 1: 1]$ to see the inducing effect, the activity increased to $55.5 \mathrm{U} / \mathrm{ml}$. However, in medium VI, where the concentration of vegetable oil was increased to $2 \% \mathrm{w} / \mathrm{v}$ ratio, there was a decrease in lipase activity to $48.7 \mathrm{U} / \mathrm{ml}$. This suggested that there was inhibition of enzyme synthesis and this could be attributed to feedback inhibition by the higher lipid concentration of medium VI.

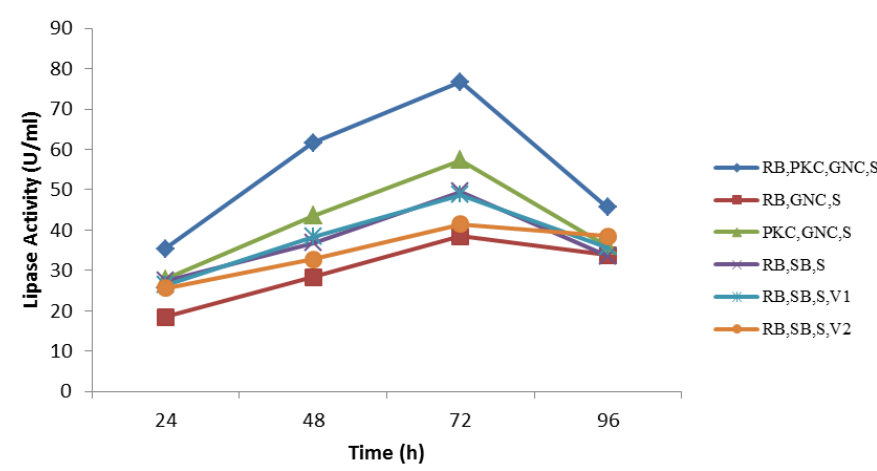

Figure 1 Lipase activity of Aspergillus niger F7-02 from different formulated media 
Factors affecting lipase activities of $A$. niger F7-02

The effect of incubation time on lipase activities of A. niger F7-02 can also be seen in Figure 1. The lipase activity of $A$. niger F7-02 in medium I increased with incubation time and peaked at $72 \mathrm{~h}$ with activity value of $76.7 \% \mathrm{U} / \mathrm{ml}$. In this study, maximum lipase activity was observed after $72 \mathrm{~h}$ of fermentation. At longer incubation periods, lipase activity decreased as nutrient and oxygen supply became growth limiting and also due to accumulation of toxic end products.

The effect of different inocula concentration of A. niger F7-02 on lipase activity at $72 \mathrm{~h}$ incubation time is shown in Figure 2. Inoculum

levels had effect on lipase activities with optimum activity at $75.4 \mathrm{U} / \mathrm{ml}$ at $1 \mathrm{~m}$ $(1 \% \mathrm{w} / \mathrm{v})$ inoculum concentration. Thus lipase activity increased with inoculum concentration and peaked at $1.0 \% \mathrm{w} / \mathrm{v}$ concentration.

The effect of the initial moisture content of the solid substrates on lipase activity of A. niger F7-02 is shown in Table 2. At varying moisture percentages with $1.0 \%$ inoculums concentration incubated at $30{ }^{\circ} \mathrm{C}$ for $72 \mathrm{~h}$. In this study the maximum lipase activity $(76.0 \mathrm{U} / \mathrm{ml})$ was observed at $60 \%(\mathrm{w} / \mathrm{v})$ moisture content at $76.0 \mathrm{U} / \mathrm{ml}$.

The effect of initial $\mathrm{pH}$ medium on the lipase activities of was investigated within $\mathrm{pH}$ range of 6.0-8.0, at $60 \%$ (w/v) moisture level, $1.0 \%$ inoculums level and $72 \mathrm{~h}$ incubation period. Lipase activity increased with $\mathrm{pH}$ with peaked at 7.0 as shown in Figure 3.

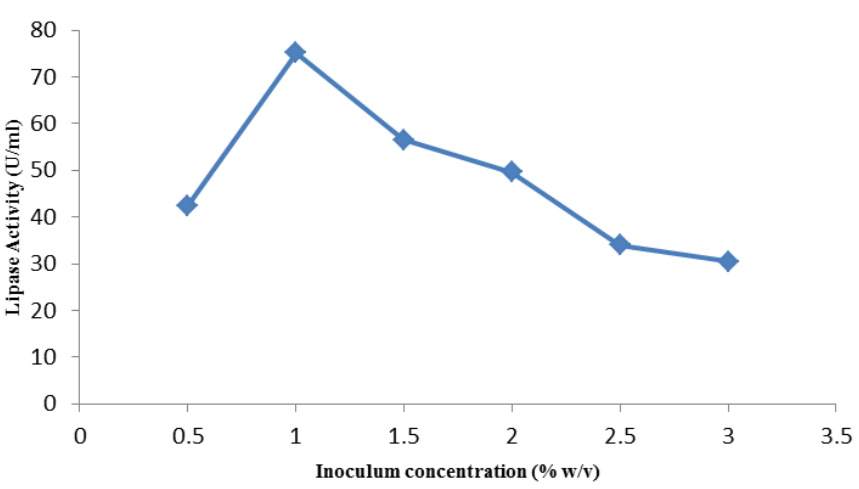

Figure 2 Effect of inoculum concentration on lipase activity of A. niger F7-02

Table 2 Effect of initial moisture content of the solid substrates on lipase activity of A. niger F7-02

Moisture level (\% w/v)

Lipase Activity (U/ml)

\begin{tabular}{ll}
40 & 20.3 \\
45 & 25.0 \\
50 & 42.2 \\
55 & 58.5 \\
60 & 76.0 \\
65 & 50.7 \\
70 & 36.5 \\
\hline
\end{tabular}

*Mean of triplicate determinations

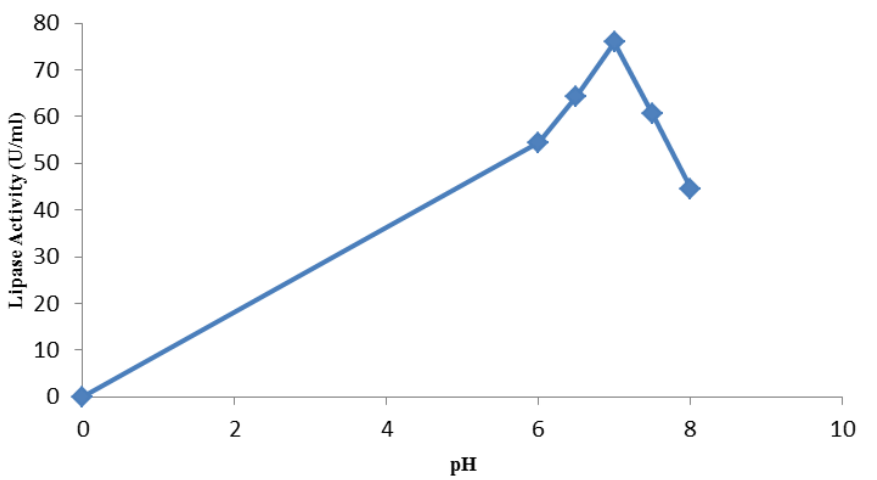

Figure 3 Effect of medium pH on lipase activitity of A. niger F7-02

\section{DISCUSSION}

\section{Isolation and screening of lipase positive moulds}

Soil has been identified as the most diverse of terrestrial habitats (Hunt et al, 2004) and the microbial community plays a fundamental role in decomposition. This prompted the search for lipase producing strains from the soil community in which microorganisms have been labeled as a rich source of new biocatalysts. Hydrolysis of olive oil by lipase produced moulds lead to the release of fatty acids and glycerols while the chromogenic dye ; bromocresol green, gave a characteristic colour change from green to yellow as a result of $\mathrm{pH}$ change in the medium. This observation conformed with the findings of Akpan (2004), who also stated that bromocresol agar medium is a simple and inexpensive medium, compared to spirit blue agar or triolein agar, which are conventionally employed for the screening of lipolytic microorganisms (Magda et al., 2004)

\section{Molecular identification}

Use of traditional methods for classification and identification of fungi has been reported to have certain drawbacks (Deene and Lingappa, 2012) such as its nonapplicability for non-cultivable organisms and also occasionally, biochemica characteristics of some organisms do not fit into patterns of any known genus and species. Molecular techniques which involves the amplification and sequencing of target regions within the ribosomal DNA gene has been reported by Buzina $\boldsymbol{e}$ al., (2001); Iwen et al., (2002); Rakeman et al., (2005); Schwarz et al., (2006) as a useful adjunctive tool for the identification of fungi. The internal transcribed spacer (ITS) regions of ITS 86 and ITS 4, which are located between the highly conserved small (18S) ribosomal subunit genes in the rRNA of the lipase producing strain have sufficiently sequence variability. This corresponds to the findings of some researchers (Brandt et al, 2005; Deen and Lingappa, 2012) who had successfully used the ITS regions for fungi identification to species level.

Optimization studies on Solid State Fermentation Process for lipases production

The use of agricultural residues which is renewable and abundantly available as substrates for lipases production has been reported. Babassu oil cake (Gombert et al., 1999), olive cake and sugar cane bagasse (Cordova et al., 1998), gingelly oil cake (Kamini et al., 1998), wheat bran (Gwen et al., 2006), rice bran (Rao et al., 1993), Jatropha curcas seed (Mahanta et al., 2008, Osho, 2013), palm kernel cake (Sarat $\boldsymbol{e t}$ al., 2010) and groundnut cake (Manoj $\boldsymbol{e t}$ al., 2010), have all been used for lipase production. In this study, the effect of various agricultural residues (rice bran, palm kernel cake, soy bean, groundnut cake and starch) combined in different ratios as sources of carbon, nitrogen and elemental supplement to support growth of $A$. niger F7-02 for lipase production was observed. Osho et al., (2014) had earlier reported the use of rice bran-physic nut waste cakes as a solid medium for Alternaria sp. MGGP 06 growth by direct incorporation (immobilization) with vegetative sponge for lipase production. This result showed there is synergistic effect in combining medium supplements for high lipase activity when compared with activity of $48.4 \mathrm{U} / \mathrm{ml}$ when wheat bran was used only (Gwen et al., 2006), $18.58 \mathrm{U} / \mathrm{ml}$ with PKC only (Sarat et al., 2010) and $45.7 \mathrm{U} / \mathrm{ml}$ with GNC only (Manoj et al., 2010). This result clearly showed that PKC has important constituent element required for lipase activity, which is lacking in rice bran. Like the conventional rice bran solid medium of Akpan and Adelaja (2004). However, in medium F, where the concentration of vegetable oil was increased to $2 \%(\mathrm{w} / \mathrm{v})$ ratio, there was a decrease in lipase activity to $48.7 \mathrm{U} / \mathrm{ml}$ suggesting inhibition of enzyme synthesis which could be attributed to feedback inhibition by the higher lipid concentration of medium VI. Lipase production is influenced by the type and concentration of carbon and nitrogen sources, the culture $\mathrm{pH}$, dissolved oxygen concentration, inoculums level and incubation time (Elibol and Ozer, 2001). Many researchers have reported different incubation periods for optimal lipase production; maximum lipase activity was achieved after $120 \mathrm{~h}$ by Mahadik et al., (2002), with Aspergillus niger on wheat bran, Sarat et al., (2010) reported maximum lipase activity by Yarrowia lipolytica after $96 \mathrm{~h}$ incubation on PKC as substrate. In another study, Benjamin and Pandey (1997) reported maximum production of lipase by Candida rugosa after $72 \mathrm{~h}$ incubation.

Reduced activity was observed with lower and higher inoculum levels which may be attributed to insufficient biomass leading to reduced product formation and too much biomass leading to the poor product formation Sarat et al., (2010). Many investigators have reported different optimal inoculum levels for lipase production with different microorganisms. For Rhizopus oligosporus, $1 \mathrm{ml}$ inoculums was reported by Ul-Haq et al., (2002), while Kamini et al., (1998) reported inoculums concentration of $1.07 \times 10^{8}$ spores $/ 10 \mathrm{~g}$ of substrate. Sarat et al., (2010) used an inoculum concentration of $2 \mathrm{ml}(20 \% \mathrm{w} / \mathrm{v})$ for maximum lipase production by Yarrowia lipolytica in PKC substrate.

Initial moisture content of substrate has been reported to play a key role in the microbial growth and for effecting biochemical activities in solid state fermentation (Babu and Rao, 2007). In this study, maximum lipase activity was 
observed at $60 \%(\mathrm{w} / \mathrm{v})$ initial moisture content at $76.0 \mathrm{U} / \mathrm{ml}$. Mahanta et al., (2008) reported $50 \%(\mathrm{w} / \mathrm{v})$ initial moisture as ideal for lipase production in Jatropha curcas seed cake as substrate, while $70 \%$ (w/v) initial moisture content was reported by Sarat $\boldsymbol{e t}$ al., (2010) with PKC as substrate. Decrease in lipase production due to higher moisture content has been attributed to decrease in porosity and hence decrease in gaseous exchange leading to suboptimal growth of microorganisms (Silman et al., 1979; Sarat $\boldsymbol{e t}$ al., 2010) while decrease in lipase activity at lower moisture content has been reported by Perez-Guerra $\boldsymbol{e}$ al. (2003) to be due to the reduction in the solubility of nutrients of the substrate which led to lower degree of swelling and also created higher water tension. Lipase activity has been reported to be affected by the $\mathrm{pH}$ of the medium as $\mathrm{pH}$ is an important parameter required for microbial growth (Sarat et al., 2010). The result obtained in this study, showed effect of $\mathrm{pH}$ of medium on lipase activity, with optimum activity recorded at $\mathrm{pH}$ 7.0. Manoj et al., (2010) also reported an optimum activity at $\mathrm{pH} 8.0$ with Bacillus subtilis OCR-4 when GNC was used as a substrate.

\section{CONCLUSION}

This study has indicated that combining agricultural residues as sources of carbon, nitrogen and elemental supplements in solid state fermentation to support the growth of $A$. niger F7-02 for lipase production led to higher lipase yield and is cost effective as compared with other studies that used single waste with expensive elemental supplements.

\section{REFERENCES}

AKPAN, I. 2004. Screening for novel fungal biocatalyst. Nigerian Journal of Microbiology, 18(1-2), 288-292.

AKPAN, I. AND ADELAJA, F.A. 2004. Production and stabilization of amylase preparations from rice bran solid medium. World Journal of Microbiology and Biotechnology, 20 ,

47-50.

http://dx.doi.org/10.1023/B:WIBI.0000013294.14446

AKPAN, I., BANKOLE, M.O., ADESEMOWO, A.M AND LATUNDE-DADA G.O. 1999. Production of alpha amylase by Aspergillus niger in a cheap solid medium using rice bran and agricultural material. Tropical Science, 39, 77-79.

BABU, I.S. AND RAO, G.H. 2007. Lipase production by Yarrowia lipolytica NCIM 3589 in solid state fermentation using mixed substrate. Research Journal of Microbiology, 2(5), 469-474. http://dx.doi.org/10.3923/jm.2007.469.474

BARNETT, H.L. AND HUNTER, B.B. 1972. Illustrated Genera of Imperfect fungi. 3rd Edn. Burgess Publishing Co., Minneapolis, 244pp.

BENJAMIN, S. AND PANDEY, A. 1997. Coconut cake: a potent substrate for production of lipase by Candida rugosa in solid state fermentation. Acta Biotechnologica, 17(3), 241-251. http://dx.doi.org/10.1002/abio.370170308

BRANDT, M. E., GAUNT, D., IQBAL, N., MCCLINTON, S., HAMBLETON, S. AND SIGLER, L. 2005. False-positive Histoplasma capsulatum Gen-Probe chemiluminescent test result caused by a Chrysosporium species. Journal of

Clinical Microbiology, 43, 1456-1458 http://dx.doi.org/10.1128/JCM.43.3.1456-1458.2005

BUZINA, W., LANG-LOIDOLT, D., BRAUN, H., FREUDENSCHUSS, K. AND STAMMBERGER, H. 2001. Development of molecular methods for identification of Schizophyllum commune from clinical samples. Journal of $\begin{array}{lll}\text { Clinical } & \text { Microbiology, } & 39,\end{array}$ http://dx.doi.org/10.1128/JCM.39.7.2391-2396.2001

CORDOVA, J., NEMMAOUI, M., ISMAILI-ALAOUI, M., MORIN, A. ROUSSOS, S., RAIMBAULT, M. AND BENJILALI, B. 1998. Lipase production by solid state fermentation of olive cake and sugar cane bagasse. Journal of Molecular Catalysis B: Enzymatic, 5(1-4), $75-78$ http://dx.doi.org/10.1016/S1381-1177(98)00067-8

DEENE, M. AND LINGAPPA, K. 2012. Molecular characterization of pigment producing fungi based on 18S rRNA Sequences. World Journal of Science and Technology, 2(1), 09-12.

ELIBOL, M. AND OZER, D. 2001. Influence of oxygen transfer on lipase production by Rhizopus arrhizus. Process Biochemistry 36, 325-329.

FREIRE, D.M.G. AND CASTILHO, L.R. 2000. Lipases produzidas por fermentação submersa e em meio sólido. Revista Brasileira de Farmácia ,81, 4856.

GOMBERT, A.K., PINTO, A.L., CASTILHO, L.R. AND FREIRE, D.M.G 1999. Lipase production by Penicillium restrictum in solid-state fermentation using babassu oil cake as substrate. Process Biochemistry, 35(1-2), 85-90 http://dx.doi.org/10.1016/S0032-9592(99)0036-9

GWEN, F., JANNY, C.A., JULIO, C., DUSTET, M. AND JOSÉ L.M.H. 2006 Production of Extracellular Lipase from Aspergillus niger by Solid-State Fermentation. Food Technology and Biotechnology, 44(2), 235-240.

HUNT, J., BODDY, L., RANDERSON, P.F. AND ROGERS, H.J. 2004. An Evaluation of $18 \mathrm{~S}$ rDNA Approaches for the Study of Fungal Diversity in Grassland Soils. Journal of Microbial ecology, 385-395. http://dx.doi.org/10.1007/s00248-003-2018-3.

IWEN, P. C., HINRICHS, S. H. AND RUPP, M. E. 2002. Utilization of the internal transcribed spacer regions as molecular targets to detect and identify human fungal pathogens. Medical Mycolaqqogy, 40, 87-109 http://dx.doi.org/10.1080/mmy.40.1.87.109.

JANAINA, N.P., JULIANA, A.B.C. AND GLÁUCIA, M.P. 2006 Characterization of Alkaline Lipase from Fusarium Oxysporum and the Effect of different Surfactants and Detergents on the Enzyme Activity. Brazilian Journal of Microbiology, 37,505-509.

KAMINI, N.R., MALA, J.G.S. AND PUVANAKRISHNAN, R. 1998. Lipase production from Aspergillus niger by solid-state fermentation using gingelly oil cake. Process Biochemistry, 33(5), 505-511 http://dx.doi.org/10.1016/S0032 9592(98)00005-3

KAREEM, S.O AND AKPAN, I. 2003. Clarification of amylase extract from moldy bran with Imarsil. Enzyme and Microbial Technology, 33, 259-261 http://dx.doi.org/10.1016/S0141-0229(03)00127-3

MAGDA, A.M., TAREK, M., SALEH, A.M AND AFAF, S.F 2004. Distribution of lipases in the Graminae: Partial purification and characterization. Bioresource Technology, 73, 227-234.

MAHADIK, N.D., PUNTAMBEKAR, U.S., BASTAWDE, K.B., KHIRE, J.M. AND GOKHALE, D.V. 2002. Production of acidic lipase by Aspergillus niger in solid state fermentation. Process Biochemistry, 38(5), 715-721 http://dx.doi.org/10.1016/S0032-9592(02)00195-2

MAHANTA, N., GUPTA, A. AND KHARE, S.K. 2008. Production of protease and lipase by solvent tolerant Pseudomonas aeruginosa PseA in solid-state fermentation using Jatropha curcas seed cake as substrate. Bioresource Technology, 99(6), 1729-1735 http://dx.doi.org/10.1016/i.biortech.2007.03.046 MANOJ, S., KUMAR, S., NEHA, S. AND KRISHNAN, K. 2010. Lipase Production by Bacillus subtilis OCR-4 in Solid State Fermentation Using Ground Nut Oil Cakes as Substrate. Current Research Journal of Biological Sciences, 2(4), 241-245.

OSHO, M.B. 2013. Production of biodiesel from Jatropha curcas seed oil by free and immobilized lipase of Aspergillus niger ATCC 1015. PhD Thesis Federal University of Agriculture, Nigeria. 55.

OSHO, M.B., POPOOLA, T. O. S., KAREEM, S. O. AND AROWOLO, T. A 2014. Transesterification of Jatropha seeds oil by vegetative sponge-immobilized lipase of Alternaria $s p$. MGGP 06 for fatty acid methyl ester production under optimized conditions. Petroleum Technology Development Journal. An International Journal, (1) 4, 56-70.

PÉREZ-GUERRA, N., TORRADO-AGRASAR, A., LÓPEZ-MACIAS, C. AND PASTRANA, L. 2003. Main characteristics and applications of solid substrate fermentation. Electronic Journal of Environmental, Agricultural and Food Chemistry, 2(3), 343-350

PRAPHAN, P. AND KIRK, L.P. 2001. Current Protocols in Food Analytical Chemistry C3.1.1-C3.1.13. Copyright by John Wiley \& Sons, Inc. http://dx.doi.org/10.1002/0471142913.fac0301s00

RAKEMAN, J.L., BUI, U., LA F., CHEN, K., HONEYCUTT, R.J. AND COOKSON, B. T. 2005. Multilocus DNA sequence comparisons rapidly identify pathogenic molds. Journal of Clinical Microbiology, 43(7), 3324-3333 http://dx.doi.org/10.1128/JCM.43.7.3324-3333.2005

RAO, P.V., JAYARAMAN, K. AND LAKSHMANAN, C.M. 1993. Production of lipase by Candida rugosa in solid state fermentation. 1: Determination of significant process variables. Process Biochemistry, 28(6), 385-389. http://dx.doi.org/10.1016/0032-9592(93)80025-C

SARAT, B.I., SITA, K.K., AND HANUMANTHA, R.G. 2010. Optimization of media constituents for the production of lipase in solid state fermentation by Yarrowia lipolytica from palm Kernal cake (Elaeis guineensis). Advances in Bioscience and Biotechnology, 1, 115-121. http://dx.doi.org/ 10.4236/abb.2010.12016.

SCHWARZ, P., BRETAGNE, S., GANTIER, J.C., GARCIA-HERMOSO, D., LORTHOLARY, O., DROMER, F. AND DANNAOUI, E. 2006. Molecular identification of zygomycetes from culture and experimentally infected tissues. Journal of Clinical Microbiology, 44, 340-349. http://dx.doi.org/10.1128/JCM.44.2.340-349.2006.

SILMAN, R.W., CONWAY, M.F., ANDERSON, R.A. AND BAGLEY, E.B. 1979. Production of aflatoxin in corn by large scale solid state substrate fermentation process. Biotechnology and Bioengineering, 21(10), 1799-1808 http://dx.doi.org/10.1002/bit260211008

UL-HAQ, I., IDREES, S. AND RAJOKA, M.I. 2002. Production of lipases by Rhizopus oligosporus by solid-state fermentation. Process Biochemistry, 37(6), 637-641 http://dx.doi.org/10.1016/S0032-9592(01)00252-7 